\title{
Retracted: Peningkatan Nilai Protein dan Serat pada Pengembangan Boba Substitusi Biji Labu Kuning
}

\author{
Alinda Rahmani*, Supriyadi, Septa Katmawanti \\ Universitas Negeri Malang, Jl. Semarang No. 5 Malang, Jawa Timur, Indonesia \\ *Penulis korespondensi, Surel: alindarahmani@gmail.com
}

Paper received: 31-9-2021; revised: 14-9-2021; accepted: 21-9-2021

\begin{abstract}
This paper has been withdrawn at the request of the author and has been retracted.
\end{abstract}

